\title{
Selenium content in selected Portuguese foodstuffs
}

Márcia Gonçalves Ventura • Maria do Carmo Freitas •

Adriano Manuel Gomes Pacheco • Thea van Meerten • Hubert Theodore Wolterbeek

Published online: 24 November 2006

(C) Springer-Verlag 2006

\section{Eur Food Res Technol (2006) s00217-006-0426-6}

Unfortunately, the name of A.M.G. Pacheco was published incomplete. The correct name is given above.

The online version of the original article can be found at http://dx.doi.org/10.1007/s00217-006-0426-6

M. G. Ventura $(\bowtie) \cdot$ M. do Carmo Freitas

ITN-Reactor, Technological and Nuclear Institute,

Apartado 21, E.N. 10,

2686-953 Sacavém, Portugal

e-mail: mventura@itn.pt
A. M. G. Pacheco
CVRM-IST, Technical University of Lisbon,
Av. Rovisco Pais 1,
1049-001 Lisbon, Portugal
T. van Meerten $\cdot$ H. T. Wolterbeek
Department of Radiochemistry,
IRI (Interfaculty Reactor Institute),
Mekelweg 15,
2629 JB Delft, The Netherlands 